\title{
Evaluation of LH-RH stimulation of testosterone as an index of reproductive status in rams and its application in wild antelope
}

\author{
A. W. Illius*, N. B. Haynes, G. E. Lamming, C. M. Howles $\dagger$, N. Fairall \\ and R. P. Millar§ \\ Department of Physiology and Environmental Science, University of Nottingham School of \\ Agriculture, Sutton Bonington, Loughborough, Leics, LE12 5RD, U.K.; $\ddagger$ Mammal Research \\ Institute, University of Pretoria, Pretoria, South Africa; and §Department of Chemical Pathology, \\ University of Capetown, Medical School, Capetown, South Africa
}

\begin{abstract}
Summary. In rams a positive correlation $(P<0.001)$ existed between average testosterone levels from 30 -min blood sampling for $18 \mathrm{~h}$ and average testosterone levels of samples taken 0,1 and $2 \mathrm{~h}$ after injection of $\mathrm{LH}-\mathrm{RH}$ administered $90 \mathrm{~min}$ after anaesthesia. Attempts were therefore made to assess testosterone status by LH-RH challenge and limited blood sampling in animals immobilized in their natural habitat. In impala (Aepyceros melampus) territorial males had higher plasma testosterone values than did bachelors after LH-RH challenge $(8.1$ compared with $2.6 \mathrm{ng} / \mathrm{ml}, P<0.05)$. In blesbok (Damaliscus dorcas), the relationship was less clear, but testicular volume was correlated with plasma testosterone concentration and with testicular responsiveness measured by testosterone produced per unit of LH $(P<0.001$ and $P<0.05$, respectively). The LH-RH challenge technique therefore has value as a measure of testicular function and permits study of ungulates in their natural environment.
\end{abstract}

\section{Introduction}

Mature (but not yearling) rams kept near cyclic ewes under controlled conditions have larger testes, higher plasma testosterone levels and greater sexual and aggressive activity than do rams with no females in close proximity (Illius, Haynes \& Lamming, 1976). These observations suggested a possible endocrine mechanism for the apparent social stability after separation of male ungulates into bachelor herds and those exerting copulation rights through territorial or harem ownership; such separation may be reinforced through testosterone levels associated with age and social situation. If proximity to females raises testosterone concentrations, which in turn increase aggression, such males would be more able to defend their position. We therefore investigated whether such a relationship existed between testicular activity and social status of ungulates in natural environments. In most male mammals, plasma testosterone concentrations fluctuate markedly over short periods and normally it is necessary to take a large number of serial blood samples at short intervals. However, frequent blood sampling over extended periods is not feasible in ungulates such as blesbok and impala in the wild state. It is also necessary to use a method of chemical capture, i.e. narcotization, and there is evidence that such methods may modify endocrine function, probably by depressing hypothalamic activity (Barraclough, 1955, 1956; Beaumont et al.,

* Present address: Edinburgh School of Agriculture, West Mains Road, Edinburgh EH9 3JG, U.K.

$\dagger$ Present address: Department of Physiology and Biochemistry, University of Reading, Whiteknights, Reading, Berks RG6 2AJ, U.K. 
1974; Peet \& Lincoln, 1977). A procedure for assessing testosterone levels in captured narcotized animals therefore had to be proposed and tested. A variety of 'provocation' tests in which hormonal responses after administration of exogenous hormones or releasing factors are assessed have been used in diagnostic medicine (Butt, 1978) and it was considered that such a test using LH-RH in animals in which $\mathrm{LH}$, and hence testosterone, had been reduced to basal levels by narcotization could be applied to assess testicular hormone production. This report describes the evaluation of such a 'provocation' test in anaesthetized rams and the application of this technique to wild impala and blesbok. The relationship between testosterone and LH in different social situations was also investigated on the basis that this may also provide a useful measure of testicular efficiency related to social status.

\section{Materials and Methods}

Rams

Studies on anaesthesia. Ten Clun Forest rams about 2 years old had blood samples taken from jugular venous cannulae for $18 \mathrm{~h}$ before and $10 \mathrm{~h}$ after administration of various combinations of drugs used to induce anaesthesia (see Table 1). Blood plasma was treated and assayed for testosterone as described below.

$L H-R H$ challenge. Details of the housing and feeding were as described by Howles, Webster \& Haynes (1980) and the rams were used as follows. The 6 Clun Forest rams in Group 1, about 2 years old, were maintained indoors under a light regimen of $8 \mathrm{~h}$ light, $16 \mathrm{~h}$ dark for 2 months and used in November. The 6 Suffolk $\times$ Swaledale/Border Leicester rams in Group 2, 3 years old, were maintained indoors from 4 months of age on an artificial lighting regimen altered to correspond to the season and used in October. In Group 3, 4 rams of the same breed as Group 2 but about 4 years old were kept indoors like those in Group 1 for 5 months and used in December. Jugular venous cannulae were placed in rams and blood samples taken into heparinized tubes every $30 \mathrm{~min}$ for 18 h. The rams were then anaesthetized by immobilizing agents suitable for chemical capture of wild ungulates, and blood sampling continued every $30 \mathrm{~min}$ for $90 \mathrm{~min}$. The rams were then given $50 \mu \mathrm{g}$ LH-RH (Hoechst, Frankfurt, West Germany) in $2 \mathrm{ml}$ saline $(9 \mathrm{~g} \mathrm{NaCl} / \mathrm{l})$ via the jugular venous cannula and blood samples were taken at 15 -min intervals for the subsequent 3-5 $\mathrm{h}$. Blood samples were centrifuged at $3000 \mathrm{~g}$ for $20 \mathrm{~min}$, the plasma removed and stored at $-15^{\circ} \mathrm{C}$ until assay. All anaesthetics were administered as a bolus via the jugular cannula and regimens differed between the groups as follows: rams in Group 1 were given $30 \mathrm{mg}$ diazepam (Roche Products Ltd, Welwyn Garden City, U.K.) in $2 \mathrm{ml}$ saline; rams in Group 2 were given $10 \mathrm{mg}$ fentanyl (Sublimaze, Janssen Pharmaceutica, Beerse, Belgium) in $2 \mathrm{ml}$ saline followed 20 min later by $10 \mathrm{mg}$ xylazine hydrochloride (Rompun: Bayer U.K. Ltd., Bury St Edmunds, U.K.); Group 3 received a combination of $10 \mathrm{mg}$ fentanyl and $10 \mathrm{mg}$ xylazine hydrochloride in $3 \mathrm{ml}$ saline.

Testicular efficiency under different social conditions. Plasma samples from the experiment of Illius et al. (1976) which showed that mature rams kept near cyclic ewes (heterosocials) had larger testes and higher plasma testosterone levels than did rams with no female contact (homosocials) were assayed for LH to permit comparison of the amount of testosterone produced per unit of LH.

\section{Blesbok and impala}

Studies on anaesthesia. In preliminary trials with semi-captive antelope the initial approach tested was to narcotize, then use a recovery agent and diazepam sedation to allow the animals to be bled at frequent intervals whilst conscious. This was not feasible because some animals died as a result of capture myopathy. Animals were then kept anaesthetized throughout and bled periodically. A first approach involving Immobilon was technically impractical, but a combination of fentanyl and xylazine proved successful for antelope under field conditions.

LH-RH challenge and testicular efficiency experiments. Thirteen male blesbok (Damaliscus 
dorcas) were captured during the breeding season in April 1977, 4 in Derdepoort (Site 1) and 9 in Rhenosterpoort (Site 2) private game reserves, Transvaal, South Africa. Before capture animals in both populations were observed for $2 \mathrm{~h}$ twice daily for 20 days (Site 1) and 15 days (Site 2). Locations of males were mapped, and their associations with females noted. This established the territorial boundaries of rutting males; bachelors were classified as those males that were nonterritorial and in bachelor groups at the time of capture (Lynch, 1974). The average number of females in the immediate vicinity of each territorial male per sighting was obtained to give a measure of female association. Selected animals were immobilized by dart gun delivering $5 \mathrm{mg}$ xylazine hydrochloride and $10 \mathrm{mg}$ fentanyl, and $100 \mathrm{mg}$ doxapram hydrochloride (Dopram: A. H. Robins Co. Ltd, Horsham, U.K.) were administered to reduce respiratory depression. Further doses of xylazine were given if animals began to recover mobility. A blood sample was obtained immediately by venepuncture and an indwelling polythene cannula was placed in the jugular vein. At $90 \mathrm{~min}$ after capture, $50 \mathrm{\mu g}$ LH-RH (Hoechst) were injected and blood samples were collected into heparinized tubes every $30 \mathrm{~min}$ or $1 \mathrm{~h}$ for $4 \mathrm{~h}$. After centrifugation, plasma was removed and stored at $-15^{\circ} \mathrm{C}$ until assay. Testicular length and width were measured by calipers in all animals.

Samples were obtained from 8 male impala (Aepyceros melampus) during the rut in May 1977 and a further 10 in May 1978 in the Kruger National Park, South Africa. Animals were classified as harem owners if sighted as single territorial males or in the company of females, or as bachelors when in the company of other males (Bramley \& Neaves, 1972). Capture was by dart gun, which delivered a dose of $5 \mathrm{mg}$ xylazine hydrochloride and $10 \mathrm{mg}$ fentanyl, and $100 \mathrm{mg}$ doxapram hydrochloride were administered to reduce respiratory depression and further doses of xylazine were given if necessary. The regimen from capture was identical to that described above for blesbok except that the plasma was heated at $60^{\circ} \mathrm{C}$ for $30 \mathrm{~min}$ to comply with veterinary restrictions on the movement of biological materials from an endemic foot and mouth area.

\section{Hormone assays}

Testosterone. Ram plasma samples were assayed as described by Purvis, Illius \& Haynes (1974). The limit of sensitivity, expressed as the value of twice the s.d. from the binding obtained with zero concentration of testosterone, was $28 \mathrm{pg} /$ tube. The intra-assay coefficient of variation (CV) between duplicate pairs (Snedecor, 1952) was $9.0 \%(n=50)$ and the inter-assay CV was $11.0 \%$ $(n=20)$. Impala and blesbok samples were assayed by the method of Millar \& Kewley (1976). Cross-reaction with other major naturally occurring steroids was $<0.1 \%$ except for $5 \alpha$ dihydrotestosterone for which it was $5 \cdot 1 \%$. Intra- and inter-assay CVs were 3.0 and $10.0 \%$ respectively. The effect of heat treatment on testosterone concentrations was studied by comparison of identical sub-samples of plasma, one of which was heated to $60^{\circ} \mathrm{C}$ for $30 \mathrm{~min}$ and the other not, from one impala (unrestricted zone) and one blesbok. Heat had no significant effect.

LH. Ram LH was assayed by the method of Scaramuzzi, Caldwell \& Moor (1970). The detection limit was $0 \cdot 2 \mathrm{ng} / \mathrm{ml}$ and the intra-assay $\mathrm{CV}$ was $8 \cdot 1 \%$. Blesbok samples were assayed by the method of Millar \& Achneht (1977) which specifically quantitates LH in a wide range of mammalian species. The antiserum employed was GDN No. 15 (kindly supplied by Dr G. D. Niswender). The limit of sensitivity was $39 \mathrm{pg} / \mathrm{ml}$ and the intra-assay CV was $2 \cdot 1 \%$. Heating impala plasma to $60^{\circ} \mathrm{C}$ for 30 min caused a $40 \%$ decrease in LH immunoreactivity; LH data from impala are therefore considered unreliable and are not discussed further.

Statistical analysis was by ANOVA and Student's $t$ test unless otherwise stated.

\section{Results}

\section{Rams}

Studies on anaesthesia. As shown in Table 1, plasma testosterone concentrations were depressed after administration of all drug combinations, even when the strong analgesic effects of Immobilon and fentanyl were reversed within $5 \mathrm{~min}$ by diprenorphine. 
Table 1. Mean plasma testosterone concentrations from blood samples taken every $30 \mathrm{~min}$ for $18 \mathrm{~h}$ before and $10 \mathrm{~h}$ after drug administration

\begin{tabular}{|c|c|c|c|}
\hline \multirow[b]{2}{*}{$\begin{array}{l}\text { No. } \\
\text { of rams }\end{array}$} & \multirow[b]{2}{*}{ Drug treatment } & \multicolumn{2}{|c|}{ Mean plasma testosterone $(\mathrm{ng} / \mathrm{ml})$} \\
\hline & & $\begin{array}{l}\text { Before drug } \\
\text { administration }\end{array}$ & $\begin{array}{l}\text { After drug } \\
\text { administration }\end{array}$ \\
\hline 2 & $\begin{array}{l}\text { Immobilon }(0.25 \mathrm{ml}) \dagger+\text { diazepam } \\
(60 \mathrm{mg}) \ddagger+\text { diprenorphine }(0.25 \mathrm{ml})^{*}\end{array}$ & $5 \cdot 6,8 \cdot 5$ & $2 \cdot 3,2 \cdot 7$ \\
\hline 1 & $\begin{array}{l}\text { Immobilon }(0.25 \mathrm{ml})+\text { diprenorphine } \\
(0.25 \mathrm{ml})^{*}\end{array}$ & $8 \cdot 6$ & $5 \cdot 2$ \\
\hline 2 & $\begin{array}{l}\text { Fentanyl }(12 \mathrm{mg})+\text { diazepam }(60 \mathrm{mg}) \\
\quad+\text { diprenorphine }(0.25 \mathrm{ml})^{*}\end{array}$ & $7 \cdot 4,8 \cdot 2$ & $2 \cdot 2,2 \cdot 9$ \\
\hline 1 & $\begin{array}{l}\text { Fentanyl }(12 \mathrm{mg})+\text { diprenorphine } \\
\quad(0.25 \mathrm{ml})^{*}\end{array}$ & $9 \cdot 1$ & $7 \cdot 2$ \\
\hline 1 & Diazepam $(60 \mathrm{mg})$ & 6.8 & $3 \cdot 0$ \\
\hline 1 & Acepromazine $(12 \mathrm{mg}) \S$ & $7 \cdot 2$ & $5 \cdot 1$ \\
\hline 1 & $\begin{array}{l}\text { Alphaxolone }(9 \mathrm{mg})+\text { alphadolone } \\
\text { acetate }(3 \mathrm{mg}) \mathscr{T}\end{array}$ & $8 \cdot 1$ & $2 \cdot 6$ \\
\hline 1 & $\begin{array}{l}\text { Halothane in } \mathrm{O}_{2} \\
\text { (enough to keep ram anaesthetized) }\end{array}$ & $5 \cdot 7$ & $2 \cdot 3$ \\
\hline
\end{tabular}

\footnotetext{
* Revivon, $3 \mathrm{mg} / \mathrm{ml}$ : Reckitt \& Coleman, Hull, U.K. Administered $5 \mathrm{~min}$ after the previous drug or drug combination. The drugs were tested in this way since it was considered that it might be desirable to administer diprenorphine very soon after immobilizing antelope and then to keep the animals tranquillized with diazepam. In the subsequent field work with antelope the use of diprenorphine and diazepam proved unnecessary since the animals remained immobilized throughout the experiment with no apparent ill-effects.

† Etorphine hydrochloride $(2.45 \mathrm{mg} / \mathrm{ml})$ + acepromazine maleate $(10 \mathrm{mg} / \mathrm{ml})$ : Reckitt \& Coleman.

$\ddagger$ Valium, $10 \mathrm{mg} / \mathrm{ml}$.

$\S$ Acetylpromazine, $10 \mathrm{mg} / \mathrm{ml}$ : C-Vet Ltd, Bury St Edmunds, U.K.

I Althesin: Glaxo, Greenford, U.K.
}

$L H-R H$ challenge experiment. A testosterone profile for an individual ram during $18 \mathrm{~h}$ without treatment, followed by LH-RH stimulation during anaesthesia is shown in Text-fig. 1. This profile is an example in which anaesthesia did not appear to depress testosterone levels (see 'Discussion'). The correlation between mean plasma testosterone concentrations from an 18-h sampling period with samples taken at 0,1 and $2 \mathrm{~h}$ after LH-RH injection in 16 rams is shown in Text-fig. 2 . Comparison of regressions showed that there were no significant differences between Groups 1,2 and 3 and the data were therefore combined. The correlation was highly significant $(P<0.001)$. Correlations with similar significance were obtained using other combinations of samples taken after injection.

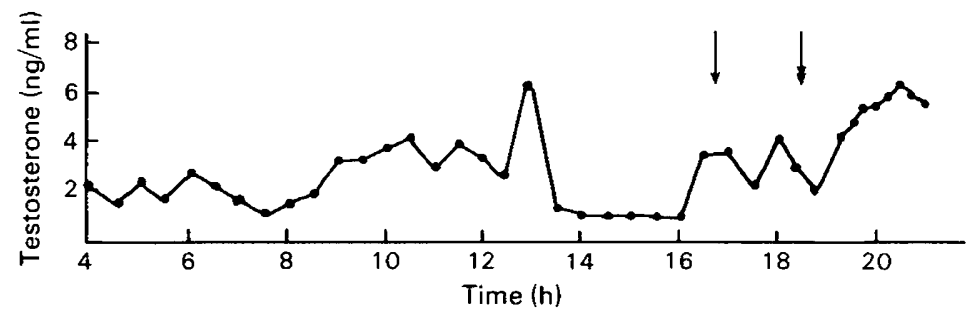

Text-fig. 1. Peripheral plasma testosterone concentrations for a ram before and after anaesthesia and injection of $50 \mu \mathrm{g}$ LH-RH. Fentanyl + xylazine hydrochloride was administered at $\downarrow$ and $\mathrm{LH}-\mathrm{RH}$ at $\$$. 


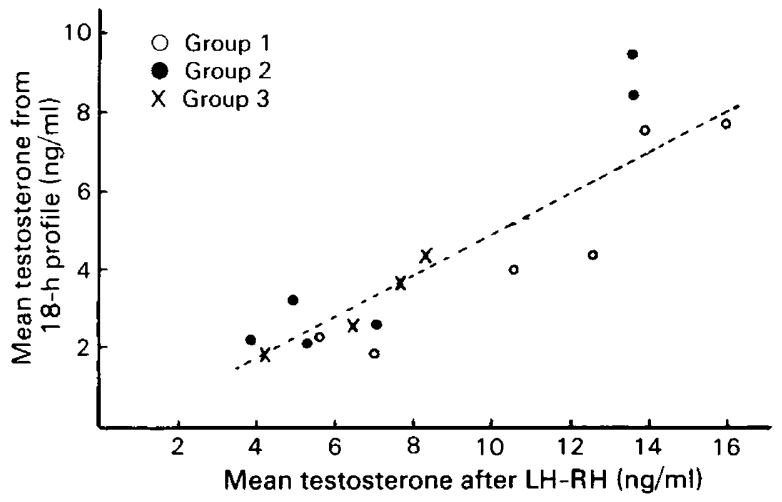

Text-fig. 2. Correlation of mean plasma testosterone from an 18-h profile for rams with sampling every $30 \mathrm{~min}$ and mean plasma testosterone from samples taken 0,1 and $2 \mathrm{~h}$ after injection of $50 \mu \mathrm{g} \mathrm{LH-RH}$. For ---, slope 0.54, intercept $-0.51, r=0.87(P<0.001)$.

Testicular efficiency under different social conditions. Examples of 18-h testosterone and LH concentrations for a ram kept adjacent to females and a ram maintained in a homosocial group are shown in Text-fig. 3. Mean testicular length and testosterone concentrations were significantly higher and LH concentrations were significantly lower in the group kept adjacent to ewes $(P<0.05)$ (see Table 2, and Illius et al. (1976) for experimental details). Testicular efficiency was significantly higher in the heterosocial group $(P<0.01)$.

(a)

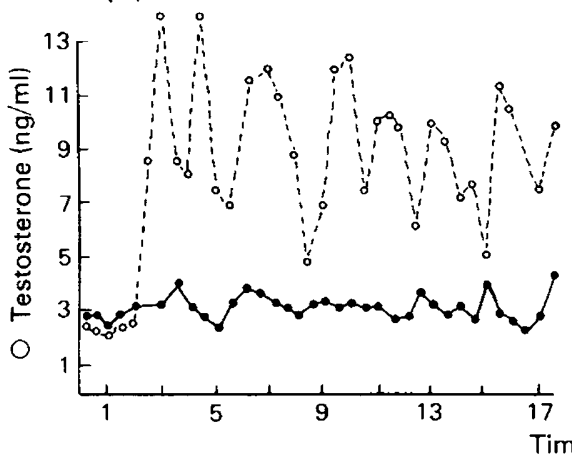

(b)

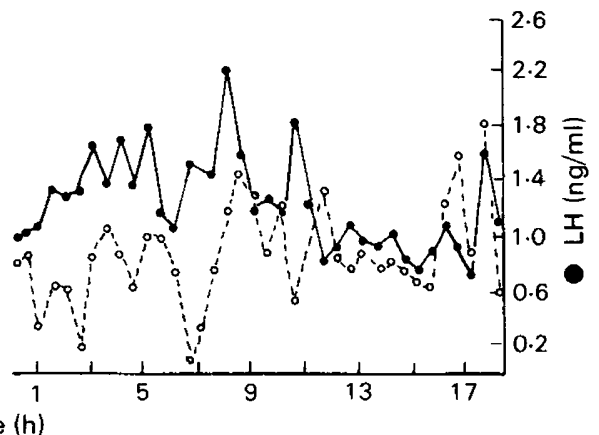

Text-fig. 3. Plasma testosterone and LH concentrations for (a) a ram maintained adjacent to cyclic ewes for 6 months, and (b) a ram maintained in a homosocial group in the absence of females (see Illius et al. (1976) for experimental protocol).

Table 2. Comparison of reproductive characteristics between rams reared next to cyclic ewes for 6 months and rams maintained away from ewes

\begin{tabular}{lccc}
\hline & $\begin{array}{c}\text { Rams kept } \\
\text { near ewes } \\
(\mathrm{N}=6)\end{array}$ & $\begin{array}{c}\text { Rams maintained } \\
\text { away from ewes } \\
(\mathrm{N}=6)\end{array}$ & Significance \\
\hline Testicular length (cm) & $14.0 \pm 0.47$ & $12.7 \pm 0.26$ & $P<0.05$ \\
Testosterone (ng/ml) from 18-h profiles & $6 \cdot 53 \pm 0.53$ & $4.94 \pm 0.42$ & $P<0.05$ \\
LH (ng/ml) from 18-h profiles & $0.76 \pm 0.07$ & $1.09 \pm 0.11$ & $P<0.05$ \\
Testicular efficiency (testosterone/LH) & $9 \cdot 30 \pm 1 \cdot 30$ & $4 \cdot 70 \pm 0.38$ & $P<0.01$ \\
\hline
\end{tabular}

Values are mean \pm s.e.m. $(t$ test). 


\section{Blesbok and impala}

LH-RH challenge and testicular efficiency experiments. The average number of females present per sighting for 8 territorial blesbok males were $7 \cdot 6,3 \cdot 8,2 \cdot 8,2 \cdot 5,0 \cdot 2,4 \cdot 3,3 \cdot 6$ and $1 \cdot 7$. All males classed as territorial returned to their original territories when released from capture. Mean testosterone and $\mathrm{LH}$ responses for blesbok and mean testosterone responses for impala 0,1 and $2 \mathrm{~h}$ after LH-RH challenge are depicted in Text-fig. 4. The overall testosterone response in territorial blesbok and the response $2 \mathrm{~h}$ after LH-RH were significantly greater than in bachelors $(P<0.05)$. There were no significant differences in LH or testicular efficiency. Testicular volume did not differ significantly between territorial and bachelor blesbok $\left(158 \cdot 3 \pm 10\right.$ and $127.4 \pm 16 \mathrm{~cm}^{3}$ respectively). Combining the data from the bachelors and territorial males gave significant correlations between testicular volume and testosterone $(r=0.76, P<0.05)$ and testicular volume and testicular efficiency $(r=0.75, P<0.05)$.

For impala, the overall testosterone response and the mean testosterone response at 1 and $2 \mathrm{~h}$ after LH-RH were significantly greater in harem owners compared to bachelors $(P<0.01)$.

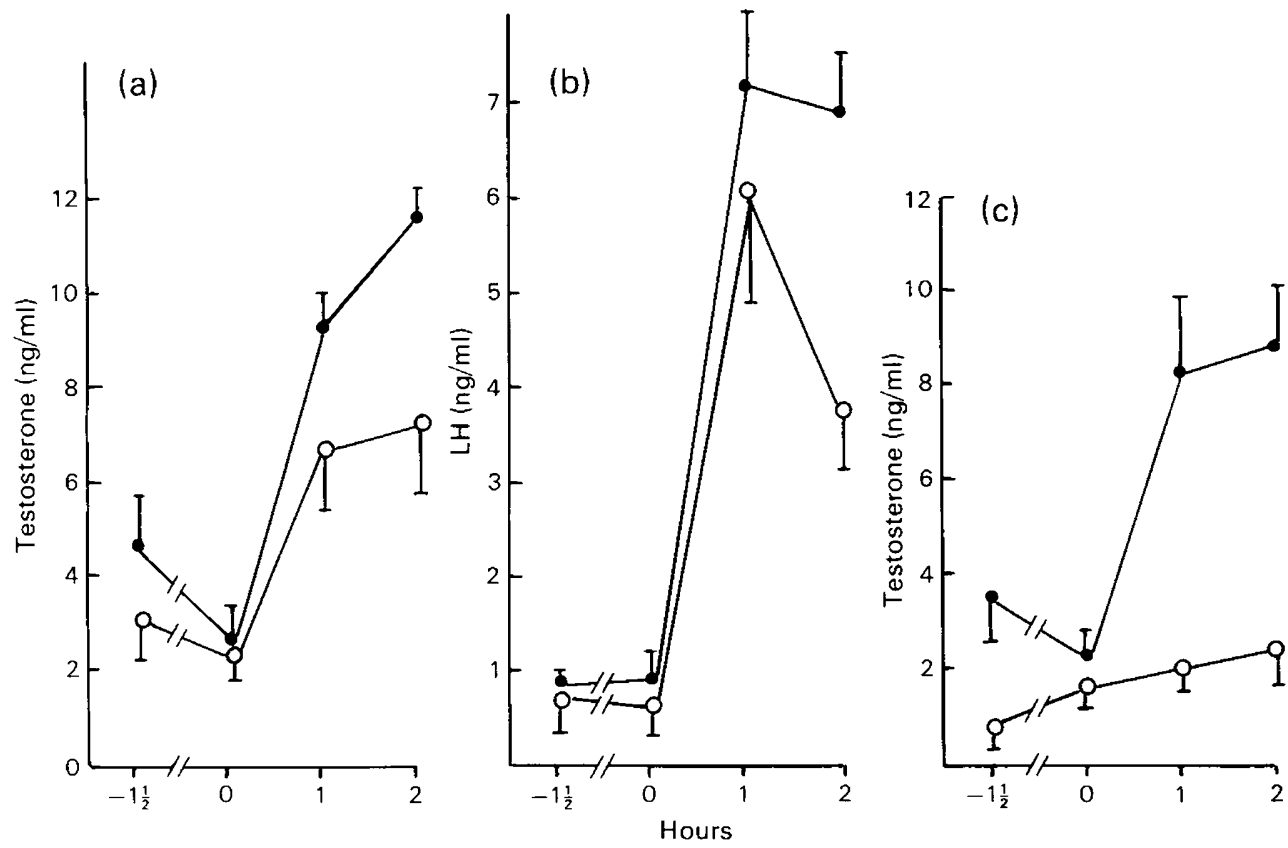

Text-fig. 4. Peripheral plasma testosterone concentration in (a) territorial $(O, N=7)$ and bachelor $(O, N=5)$ blesbok and (c) territorial $(O, N=11)$ and bachelor $(O, N=7)$ impala at capture $\left(-1 \frac{1}{2} \mathrm{~h}\right)$ and 0,1 and $2 \mathrm{~h}$ after injection of $50 \mu \mathrm{g} \mathrm{LH}-\mathrm{RH}(0 \mathrm{~h})$. Equivalent LH concentrations for blesbok are shown in (b).

\section{Discussion}

The good correlation between mean plasma testosterone concentration from 3 blood samples taken after anaesthesia and LH-RH challenge in rams and mean plasma testosterone concentration from a detailed profile study suggests that the challenge technique could have value in providing a simple method of establishing the testosterone status of an animal. This is particularly so since the overall correlation was obtained with rams of different breeds and under different environmental conditions. Whilst the original intention was to reduce testosterone levels to basal by blocking release of LH-RH from the hypothalamus and hence $\mathbf{L H}$ release from the anterior pituitary (Peet \& 
Lincoln, 1977), this did not happen in all rams (see Text-fig. 1). Nevertheless, a good correlation was still obtained. In blesbok and impala a more uniform reduction in testosterone levels occurred after narcotization. Since the completion of this work, it has been reported that there is a highly significant correlation between mean testosterone from 2 samples obtained from unanaesthetized bulls after administration of hCG and a previous testosterone concentration obtained from a detailed profile (Sundby \& Velle, 1980).

In the experiment demonstrating increased plasma testosterone in rams as a result of exposure to long-term female proximity, this increased testosterone does not appear to result ultimately from increased LH secretion. The sensitivity of the brain to negative feedback of testosterone is apparently similar in heterosocial and homosocial rams, since those with higher testosterone (heterosocials) had low LH and vice versa for the homosocial group. Assuming that plasma testosterone and LH concentrations reflect secretion rates, the estimate of efficiency (testosterone per unit of $\mathbf{L H}$ ) revealed that in the heterosocial rams LH was more effective in stimulating testosterone secretion than it was in the homosocials. Thus, testicular efficiency measurements could offer a further method of assessing the degree of testicular function.

Application of the challenge technique in impala and extrapolation from the ram study gave results which suggest that, in the natural situation, testosterone levels are higher in territorial males than in bachelors. This accords with the observation of Bramley \& Neaves (1972) that plasma testosterone concentrations were significantly higher in single blood samples taken from territorial male impala than in those from bachelor impala. However, the difference in testosterone values between the two groups in the single samples taken at capture in the current study was not significant and the challenge technique was necessary to demonstrate significant differences in testosterone status.

In the blesbok study, results were less clear, possibly because it is more difficult to classify bachelor and territorial blesbok than impala, although in all measurements presumed territorial males tended to have higher values than did presumed bachelors. The relative lack of significant differences may be because, unlike the ram study, testicular volumes were not significantly different between the two groups of blesbok and the hormone difference between the groups of rams disappears if the data are adjusted for testicular size. That testicular size is an important feature is borne out by the significant correlations found between testicular volume and testosterone levels and testicular volume and testicular efficiency when data for bachelor and territorial males were combined.

In summary, these preliminary studies on impala and blesbok suggest that reproductive hormone differences do occur between different male social groups, and the simple LH-RH challenge technique could be useful in more detailed studies on male animals captured in the wild state.

We thank the Agricultural Research Council of Great Britain and the Medical Research Council and CSIR of South Africa for funding, staff of the MRI for technical assistance, and Dr G. A. Lincoln for the measurements of ram LH values.

\section{References}

Barraclough, C.A. (1955) Blockade of the release of pituitary gonadotrophin by reserpine. Fedn Proc. Fedn Am. Socs exp. Biol. 14, 9-10.

Barraclough, C.A. (1956) Blockade of the release of pituitary gonadotrophin by chlorpromazine. Anat. Rec. 124, 255.

Beaumont, P.J.V., Gelder, M.G., Friesen, H.G., Harris, G.W., McKinnon, P.C.B., Mandelbrote, B.M. \& Wiles, D.H. (1974) The effects of phenothiazines on endocrine function. I Patients with inappropriate lactation and amenorrhoea. Br. J. Psychiat. 124, 413419.

Bramley, P.S. \& Neaves, W. B. (1972) The relationship between social status and reproductive activity in male impala, Aepyceros melampus. J. Reprod. Fert. 31, 77-81.

Butt, W.R. (1978) The diagnosis of ovulating disorders. In Control of Ovulation, pp. 357-371. Eds D. B. Crighton, N. B. Haynes, G. R. Foxcroft \& G. E. Lamming. Butterworths, London. 
Howles, C.M., Webster, G.M. \& Haynes, N.B. (1980) The effect of rearing under a long or short photoperiod on testis growth, plasma testosterone and prolactin concentrations and the development of sexual behaviour in rams. J. Reprod. Fert. 60, 437-447.

Illius, A.W., Haynes, N.B. \& Lamming, G.E. (1976) Effects of ewe proximity on peripheral plasma testosterone levels and behaviour in the ram. $J$. Reprod. Fert. 48, 25-32.

Lynch, C.D. (1974) A behaviour study of blesbok, Damaliscus dorcas phillipsi, with special reference to territoriality. Memoirs Van die Nasionale Museum, No. 8, Bloemfontein, South Africa.

Millar, R.P. \& Achneht, C. (1977) Application of ovine luteinizing hormone (LH) radioimmunoassay in the quantification of LH in different mammalian species. Endocrinology 101, 760-768.
Millar, R.P. \& Kewley, C. (1976) Production of a specific antiserum for testosterone. S. Afr. med. J. 50, 10211024.

Peet, M.J. \& Lincoln, G.A. (1977) Blockade of episodic gonadotrophic secretion by Immobilon in ovariectomized ewes. J. Reprod. Fert. 50, 97-100.

Purvis, K., Mlius, A.W. \& Haynes, N.B. (1974) Plasma testosterone concentrations in the ram. J. Endocr. 61, 241-253.

Scaramuzzi, R.J., Caldwell, B.V. \& Moor, R.M. (1970) Radioimmunoassay of $\mathrm{LH}$ and estrogen during the estrous cycle in the ewe. Biol. Reprod. 3, 110-119.

Snedecor, G.W. (1952) Query 92. Biometrics 8, 85-86.

Sundby, A. \& Velle, W. (1980) Plasma concentration of testosterone in young bulls in relation to age, rate of weight gain and stimulation with human chorionic gonadotrophin. J. Endocr. 86, 465-469. 